\title{
Factors Influencing the in vitro Production of Staphylococcal Coagulase
}

\author{
By G. E. DAVIES \\ Imperial Chemical Industries Ltd., Biological Laboratories, \\ Hexagon House, Blackley, Manchester
}

SUMMARY: The amount of coagulase formed in vitro by coagulase-positive staphylococci depends on: the age of the bacterial cells, coagulase being produced only during the latter part of the lag-phase of growth; the period of incubation of the bacterial cells under ideal conditions, the optimum period depending upon the age of the cells when incubation starts; the initial concentration of bacteria. It also depends on the presence in the medium of a fermentable sugar and a factor found in brain-heart infusion and partially replaceable by peptone; the salt concentration in the medium; the initial pH value of the medium; the temperature of incubation: and upon substances present in rabbit serum and, to a lesser extent, horse serum, human serum and egg yolk, egg white and commercial nucleic acid not showing this effect. The activity of rabbit serum is destroyed by treatment with pepsin. Provided that the requisite conditions are met, cell-free coagulase which clots rabbit plasma within a few minutes, can be prepared in less than one hour.

Since the demonstration that coagulase is an important factor in determining the pathogenicity of staphylococci, many papers on this substance have appeared (e.g. Christie \& Keogh, 1940; Fairbrother, 1940; Fisher, 1936; Spink \& Vivino, 1942; Walston, 1935). Following the lead of Smith \& Hale (1944), most workers have attempted to elucidate the mechanism of the reaction of coagulase with fibrinogen (Kaplan \& Spink, 1948; Miale, 1949; Tager, 1948 $a$; Tager \& Hales, 1948). Attempts have also been made to purify coagulase (Tager, 1948b; Walker, Derow \& Schaffer, 1948) but little attention has been given to the way in which the staphylococci produce coagulase. With a view to investigating the contribution of coagulase to the virulence of staphylococci we have studied the factors which govern its production in vitro.

The terminology of the coagulase phenomenon has become confused. We have chosen the simplest names which are in common use. The active principle produced by the organisms in broth is referred to as 'pro-coagulase'. This, together with a substance found in certain sera 'coagulase-reacting factor', forms 'coagulase' which transforms fibrinogen into fibrin.

\section{EXPERIMENTAL METHODS}

Inoculum. A 24-hr. culture of Staphylococcus aureus (various strains were used) in Wright's broth (Wright, 1933) was centrifuged and the cells suspended in sterile $0.85 \%$ saline. Large clumps of cells were broken up by shaking with glass beads and the strength of the suspension determined by comparison with standard opacity tubes. 
Production of coagulase. The inoculum was added to the productionmedium, both having been previously warmed to $37^{\circ}$. The mixture was incubated at $37^{\circ}$ for the desired period and then thiomersalate was added to give a final concentration of $0.01 \%$. Coagulase, if present, was contained in the supernatant formed after centrifuging at 4,000 r.p.m. for $10 \mathrm{~min}$. This procedure provided a clear liquid from which over $99 \%$ of the bacterial cells had been removed.

Assay of coagulase. One-tenth ml. of the supernatant was mixed in 3 in. $\times$ $3 / 8$ in. tubes with $0.9 \mathrm{ml}$. of $10 \%(\mathrm{v} / \mathrm{v})$ rabbit plasma in saline. The tubes were incubated in a thermostatically controlled water-bath at $37^{\circ}$. The degree of clotting was recorded at intervals as follows: $0=$ No clot, liquid clear; $1=$ trace clot, liquid clear; $2=50 \%$ clot, liquid slightly turbid; $3=$ almost complete clot; $4=$ complete clot.

An arbitrary unit of coagulase activity was derived from the expression $K t=100$, where $t$ is the time in min. for a ' 2 ' clot to form under the conditions defined above.

\section{RESULTS}

In the usual method of testing for coagulase production by staphylococci a portion of broth culture is added to diluted plasma (Fisk, 1940; Williams \& Harper, 1946). When the supernatant from this culture is used instead of the whole culture it can be shown that it contains only a small proportion of the total pro-coagulase. A little more pro-coagulase is obtained in the first saline-washing of the cells but none in subsequent washings. The washed cells, however, clot the plasma at about the same titre as the original culture (Table 1).

Table 1. Production of pro-coagulase by washed staphylococci

\begin{tabular}{|c|c|c|c|}
\hline \multirow[b]{2}{*}{$\begin{array}{c}\text { Source of } \\
\text { pro-coagulase }\end{array}$} & \multicolumn{3}{|c|}{ Highest dilution giving ' 2 ' clot } \\
\hline & $\begin{array}{l}1 \mathrm{hr} . \\
\text { reading }\end{array}$ & $\begin{array}{l}2 \mathrm{hr} . \\
\text { reading }\end{array}$ & $\begin{array}{l}3 \mathrm{hr} \text {. } \\
\text { reading }\end{array}$ \\
\hline Whole culture & $1 / 24$ & $1 / 48$ & $1 / 192$ \\
\hline Supernatant & $1 / 6$ & $1 / 12$ & $1 / 12$ \\
\hline $\begin{array}{l}\text { 1st washing } \\
\text { 2nd washing }\end{array}$ & -1 & $\begin{array}{l}\text { agulase a } \\
\text { agulase a }\end{array}$ & $\longrightarrow$ \\
\hline Washed cells & $1 / 24$ & $1 / 24$ & $1 / 192$ \\
\hline
\end{tabular}

We found that thiomersalate $(0.01 \%)$ inhibited the production of procoagulase by the washed cells but had no action on the pro-coagulase in the supernatant or on the coagulase formed from this pro-coagulase in the presence of plasma. Thiomersalate was, therefore, used in subsequent experiments whenever we wanted to stop the production of pro-coagulase without affecting its action or that of coagulase. It was apparent from the experiments shown in Table 1 that, under the conditions described, the staphylococci were producing pro-coagulase within a very short time, possibly before the cells started to divide. The rapid production of pro-coagulase was proved by the 
following experiment. A concentrated suspension of staphylococcal cells (strain BB) was prepared by suspending the washed cells from ten $10 \mathrm{ml} .24-\mathrm{hr}$. broth cultures in $7 \mathrm{ml}$. of saline. One $\mathrm{ml}$. of this suspension was added to each of 9 sterile $50 \mathrm{ml}$. conical Pyrex flasks: 3 containing $10 \mathrm{ml}$. of Difco brain-heart infusion, 3 containing $9 \mathrm{ml}$. of this infusion and $1 \mathrm{ml}$. of rabbit plasma, and 3 containing $1 \mathrm{ml}$. of the plasma and $9 \mathrm{ml}$. of saline buffered to $\mathrm{pH} \mathrm{7 \cdot 6}$. After 1,2 and $2 \frac{1}{2} \mathrm{hr}$. incubation at $37^{\circ}$, one flask of each set was withdrawn from the incubator, the contents centrifuged and thiomersalate added to the supernatants. The coagulase titre of the supernatants against $10 \%$ rabbit plasma in saline was then determined.

The results showed that both broth and plasma must be present for rapid production of coagulase. The supernatant from the complete medium, which had been incubated for only $1 \mathrm{hr}$., clotted the plasma in $2 \mathrm{hr}$. at a dilution of $1 / 192$, supernatants from the media lacking either broth or plasma, and incubated for $2 \frac{1}{2} \mathrm{hr}$., failed to clot the plasma in $2 \mathrm{hr}$. at a dilution of $1 / 6$. The active supernatants contained coagulase rather than pro-coagulase since they clotted both plasma and solutions of pure fibrinogen at about the same rate. Living cultures did not clot the fibrinogen solution. The rabbit plasma in the above medium could be replaced by rabbit serum but not by bovine fibrinogen. These experiments indicated that there are two essential factors or groups of factors for the production of coagulase. One is present in rabbit serum and the other in brain-heart infusion.

\section{Experiments on the serum-factor necessary for coagulase production}

In order to investigate the effect of serum on bacteria of varying age, the experiment summarized in the following diagram was performed:

Flasks containing staphylococci in brain-heart infusion for

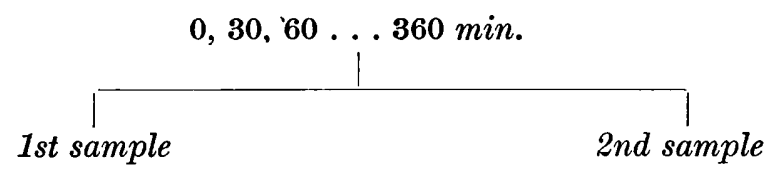

Withdrawn from flask, thiomersalate added, liquid centrifuged.

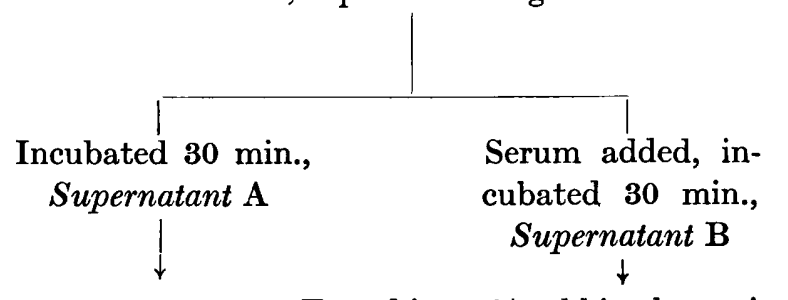

Serum added to flask, incubated $30 \mathrm{~min}$., thiomersalate added, liquid centrifuged.

Tested in $10 \%$ rabbit plasma in saline.

We thus had three supernatants from each flask: A, containing procoagulase produced in the absence of serum; $\mathbf{B}$, containing coagulase formed 
by the action of serum on the cell-free pro-coagulase in $\mathrm{A}$; $\mathrm{C}$, containing coagulase formed by the action of serum on the living cells.

Table 2 and Fig. 1 show that pro-coagulase was first detectable in supernatant $A$ when the cocci had been incubated for $60 \mathrm{~min}$. The amount of pro-coagulase was small (less than 10 units $/ \mathrm{ml}$.) and increased to only 45 units $/ \mathrm{ml}$. after incubation for a further $300 \mathrm{~min}$. When $10 \%$ of rabbit serum was added at the start of incubation, a large amount (143 units/ml.) of coagulase was produced within $30 \mathrm{~min}$. The results were similar when serum was added to cocci which had been incubated for $30 \mathrm{~min}$. However, cocci

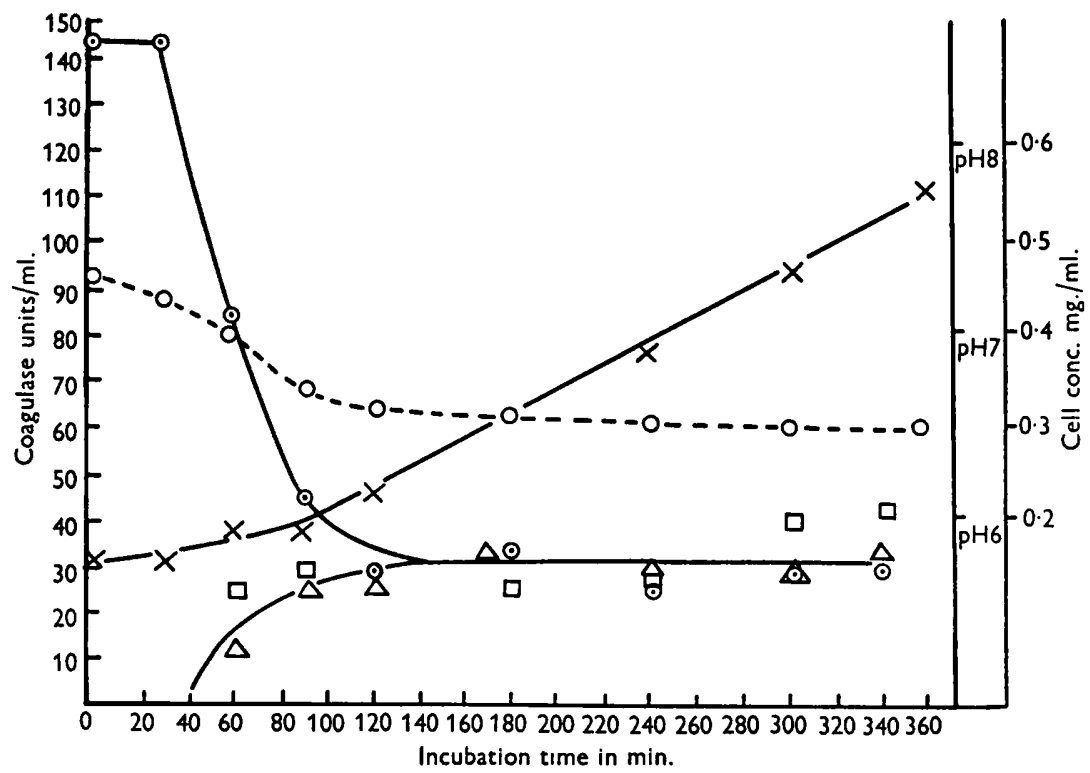

Fig. 1. Influence of rabbit serum on the production of coagulase by staphylococci.

Organism incubated for varying periods in brain-heart infusion; $\odot-\odot$, rabbit serum added and mixture incubated $30 \mathrm{~min}$. and then centrifuged; $\square-\square$, culture centrifuged and supernatant incubated 30 min.; $\triangle-\Delta$, culture centrifuged, rabbit serum added to supernatant and mixture incubated for $30 \mathrm{~min}$.; $x-x$, concentration of bacteria as determined by opacity tubes; $\bigcirc \cdots-\cdots, \mathrm{pH}$ of culture in brain-heart infusion.

incubated for $60 \mathrm{~min}$. before the addition of serum produced only 84 units coagulase $/ \mathrm{ml}$. in the subsequent $30 \mathrm{~min}$. and those incubated for $120 \mathrm{~min}$. produced only 29 units $/ \mathrm{ml}$., an amount corresponding to the pro-coagulase formed in the same time by cocci which had not been acted on by serum (column $\mathrm{C}$, Table 2). Contact between serum and living bacteria was essential for coagulase production; serum added to the cell-free supernatant for $30 \mathrm{~min}$. produced coagulase in amount corresponding to the pro-coagulase already present (column B). Measurements of $\mathrm{pH}$ values and determinations of cell concentrations indicated that the period during which serum can stimulate the bacteria to produce coagulase corresponds to the lag-phase of growth. 
Rabbit serum exerts its maximal effect with great rapidity provided that the bacteria are at the appropriate stage of growth (i.e. towards the end of the lag-phase; Table 3).

Table 2. Influence of rabbit serum on the production of coagulase by staphylococci; effect of adding serum to cells of varying age

Strain : E.B.1.; 0.4 mg. dry wt. cells $/ \mathrm{ml}$. Medium : brain-heart infusion, pH 7.6. Incubation temperature: $37^{\circ}$.

\begin{tabular}{|c|c|c|c|c|c|c|c|}
\hline \multirow[b]{2}{*}{$\begin{array}{l}\text { Age of } \\
\text { cells } \\
\text { (min.) }\end{array}$} & \multirow[b]{2}{*}{$\begin{array}{l}\text { Conc. of } \\
\text { cells } \\
(\mathrm{mg} \cdot / \mathrm{ml} .)\end{array}$} & \multicolumn{2}{|c|}{$\begin{array}{l}\text { Supernatant from serum } \\
\text { with cells for } 30 \mathrm{~min} \text {. (C) }\end{array}$} & \multicolumn{2}{|c|}{$\begin{array}{l}\text { Serum with super- } \\
\text { natant from cells for } \\
30 \text { min. (B) }\end{array}$} & \multicolumn{2}{|c|}{$\begin{array}{l}\text { Supernatant } \\
\text { from cells (A) }\end{array}$} \\
\hline & & pH & $\begin{array}{l}\text { Coagulase } \\
\text { units } / \mathrm{ml} \text {. }\end{array}$ & pH & $\begin{array}{l}\text { Coagulase } \\
\text { units } / \mathrm{ml} \text {. }\end{array}$ & pH & $\begin{array}{l}\text { Coagulase } \\
\text { units } / \mathrm{ml} \text {. }\end{array}$ \\
\hline $\mathbf{0}$ & $0 \cdot 16$ & $7 \cdot 23$ & 143 & $7 \cdot 21$ & $<10$ & $7 \cdot 37$ & $<10$ \\
\hline 30 & $0 \cdot 16$ & 7.07 & 143 & $7 \cdot 11$ & $<10$ & $7 \cdot 26$ & $<10$ \\
\hline 60 & $0 \cdot 19$ & $6 \cdot 78$ & 84 & $6 \cdot 84$ & 12 & $7 \cdot 07$ & 25 \\
\hline 90 & $0 \cdot 19$ & $6 \cdot 63$ & 45 & 6.65 & 25 & 6.83 & 29 \\
\hline 120 & 0.23 & $6 \cdot 60$ & 29 & $6 \cdot 52$ & 25 & $6 \cdot 73$ & 29 \\
\hline 180 & $0 \cdot 32$ & 6.57 & 33 & $6 \cdot 46$ & 33 & $6 \cdot 66$ & 25 \\
\hline 240 & $0 \cdot 38$ & 6.55 & 25 & $6 \cdot 43$ & 29 & 6.63 & 27 \\
\hline 300 & 0.42 & $6 \cdot 63$ & 29 & $6 \cdot 42$ & 29 & $6 \cdot 64$ & 40 \\
\hline 360 & 0.56 & 6.50 & 29 & $6 \cdot 42$ & 33 & 6.64 & 45 \\
\hline
\end{tabular}

See Fig. 1.

Table 3. Influence of rabbit serum on the production of coagulase by staphylococci: effect of varying the age of cells and the time of their contact with serum

Strain: E.B.1; 0.3 mg. dry wt. cells $/ \mathrm{ml}$. Medium: brain-heart infusion $+10 \%$ rabbit serum, $\mathrm{pH} 7 \cdot 3$. Incubation temperature, $37^{\circ}$.

Period of incubation of cells in broth before addition of serum (min.)

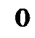

10

20

30

40

60
Coagulase units $/ \mathrm{ml}$. formed after serum has been in contact for

\begin{tabular}{rcccc}
\hline 5 min. & 10 min. & 20 min. & 30 min. & 60 min. \\
$<10$ & $<10$ & $<10$ & 15 & 30 \\
$<10$ & $<10$ & $<10$ & 15 & 15 \\
15 & 15 & 15 & 20 & 40 \\
40 & 60 & 50 & 50 & 50 \\
60 & 60 & 50 & 60 & 100 \\
100 & 100 & 100 & 80 & 80
\end{tabular}

Horse serum, horse plasma and sheep serum are less effective than rabbit serum. With each of these the highest titre of coagulase is reached at about the same time as with rabbit serum and further incubation does not cause the titre to decline. Egg yolk is about as active as horse serum. Egg white, ribo- and deoxyribonucleic acids are inactive. Rabbit serum when treated with pepsin loses its power to promote the formation of coagulase, indicating that the active portion is either a protein or is associated with a protein. Increase in the concentration of rabbit serum above $10 \%$ does not result in 
increased production of coagulase; the optimal concentration is in the neighbourhood of $10 \%$. A large excess $(80 \%)$ of serum decreases the yield of coagulase, probably because of the presence of an inhibitor in the serum.

\section{Experiments on the broth-factors necessary for coagulase production}

All the foregoing experiments were done using Difco brain-heart infusion as the source of 'broth-factors'. Our efforts were then directed to find a medium simpler than this complex infusion. We found that a medium containing peptone, sodium chloride, glucose and phosphate buffer at $\mathrm{pH} \mathbf{8 . 0}$ could partially replace the infusion, as shown in Table 4. In these and in all subsequent experiments in this section, $10 \%$ rabbit serum was used as source of serum-factor. The amount of coagulase produced was largely independent of the concentration of peptone between 0.5 and $5.0 \%$ and of the concentration of glucose, also between 0.5 and $5.0 \%$. The ratio of activity between brain-heart infusion and the optimal glucose-peptone medium varied slightly in different experiments but on the whole the infusion was rather more efficient.

Table 4. Effect of varying the concentration of glucose and peptone on the production of coagulase by staphylococci

Strain : B.B.; 0.35 mg. dry wt. cells $/ \mathrm{ml}$. Medium: Evans Peptone; 0.5\% glucose; $\mathrm{NaCl}$; $0.25 \% \mathrm{Na}_{2} \mathrm{HPO}_{4} ; 10 \%$ rabbit serum; $\mathrm{pH} 7 \cdot 9$. Incubation temperature $37^{\circ}$.

$\begin{array}{ccc}\begin{array}{c}\text { Peptone } \\ (\%)\end{array} & \begin{array}{c}\text { Glucose } \\ (\%)\end{array} & \begin{array}{c}\text { Coagulase units } / \mathrm{ml} . \\ \text { formed in } 1 \mathrm{hr} .\end{array} \\ 5 \cdot 0 & 0.5 & 130 \\ 2.0 & 0.5 & 170 \\ 1.0 & 0.5 & 140 \\ 0.5 & 0.5 & 130 \\ 1.0 & 0 & 70 \\ 1.0 & 1 \cdot 0 & 140 \\ 1.0 & 2 \cdot 0 & 160 \\ 1.0 & 5 \cdot 0 & 130 \\ \text { Brain-heart infusion, pH } \mathbf{7 \cdot 3}: & 140\end{array}$

Ether-extraction of the brain-heart infusion did not alter its capacity to serve as a medium for coagulase production and addition of the extracted lipids to the peptone-glucose solution did not improve the latter. Acidhydrolysed casein was about half as efficient as peptone when both were prepared in $0.5 \%$ glucose buffer. The yield of coagulase was independent of the concentration of casein hydrolysate between 0.5 and $5.0 \%$. We considered it possible that peptone and casein hydrolysate were less efficient than the infusion because they were poorer as growth media, i.e. they would prolong the lag-phase so that the period of maxirnal coagulase production would be reached later. However with three concentrations of peptone the yield of coagulase after incubation for $2 \mathrm{hr}$. was the same as that after $1 \mathrm{hr}$. 


\section{Influence of $p H$ on the production of coagulase}

It can be seen from Table 2 that, concurrent with the production of coagulase in the complete medium, there is a rapid fall in the $\mathrm{pH}$ value of the medium. When the $\mathrm{pH}$ of the medium was kept between $7 \cdot 3$ and $7 \cdot 6$, the maximum yield of coagulase was reached rather earlier but was not higher than that produced when the $\mathrm{pH}$ value was allowed to fall (Table 5). In these experiments, again, the results indicated that coagulase was produced during the lag-phase of growth.

Table 5. Influence of $p H$ value on production of coagulase by staphylococci; comparison of neutralized with non-neutralized medium

Strain: B.B.; $0.47 \mathrm{mg}$. dry wt. cells $/ \mathrm{ml}$. Medium: brain-heart infusion $+10 \%$ rabbit serum. Incubation temperature $37^{\circ}$.

\begin{tabular}{|c|c|c|c|c|c|c|}
\hline \multirow{2}{*}{$\begin{array}{c}\text { Period } \\
\text { of incubation } \\
\text { (min.) }\end{array}$} & \multicolumn{3}{|c|}{ pH not controlled } & \multicolumn{3}{|c|}{ pH kept at between $7 \cdot 3-7 \cdot 6$} \\
\hline & $\mathrm{pH}$ & $\begin{array}{l}\text { Cell conc. } \\
\text { (mg./ml.) }\end{array}$ & $\begin{array}{l}\text { Coagulase } \\
\text { units } / \mathrm{ml} \text {. }\end{array}$ & $\mathbf{p H}$ & $\begin{array}{l}\text { Cell conc. } \\
(\mathrm{mg} \cdot / \mathrm{ml} .)\end{array}$ & $\begin{array}{l}\text { Coagulase } \\
\text { units } / \mathrm{ml} \text {. }\end{array}$ \\
\hline $\mathbf{0}$ & $7 \cdot 30$ & 0.47 & $\mathbf{0}$ & $7 \cdot 30$ & $0 \cdot 47$ & $\mathbf{0}$ \\
\hline 10 & $7 \cdot 20$ & 0.47 & 35 & $7 \cdot 30$ & 0.47 & $<10$ \\
\hline 20 & $7 \cdot 16$ & $0 \cdot 47$ & 120 & $7 \cdot 38$ & 0.47 & 10 \\
\hline 30 & 6.99 & 0.59 & 170 & $7 \cdot 40$ & 0.47 & 145 \\
\hline 40 & $6 \cdot 89$ & $0 \cdot 71$ & 120 & $7 \cdot 34$ & 0.59 & 200 \\
\hline 50 & $6 \cdot 89$ & $0 \cdot 71$ & 170 & $7 \cdot 60$ & $\mathbf{0 . 5 9}$ & 250 \\
\hline 60 & $6 \cdot 73$ & $0 \cdot 75$ & 200 & $7 \cdot 60$ & $0 \cdot 85$ & 200 \\
\hline 90 & $6 \cdot 53$ & $0 \cdot 85$ & 290 & $7 \cdot 45$ & $\mathbf{0} \cdot \mathbf{8 5}$ & 200 \\
\hline 120 & $6 \cdot 47$ & 0.94 & 290 & $7 \cdot \mathbf{3 4}$ & $0 \cdot 85$ & 200 \\
\hline 180 & $6 \cdot 42$ & 0.94 & 290 & $7 \cdot 30$ & $0 \cdot 85$ & 200 \\
\hline 360 & $6 \cdot 34$ & 0.94 & 200 & - & 一 & - \\
\hline
\end{tabular}

The yield of coagulase does, however, depend upon the initial $\mathrm{pH}$ value of the medium as is shown in Table 6 and Fig. 2. With an initial $\mathrm{pH}$ of $6 \cdot 1$ no coagulase was produced. Increase in initial $\mathrm{pH}$ resulted in increased yield of coagulase which reached a maximum with initial $\mathrm{pH}$ values between 8.4 and 9.3. With an initial $\mathrm{pH}$ value of $9 \cdot 3$ the rate of coagulase production was slower but the final yield was greater (Fig. 2). Fig. 3 shows that coagulase is produced when the actual $\mathrm{pH}$ of the medium is between about 7 and 8.5 with a maximum yield at $\mathrm{pH} \mathbf{7 \cdot 6}$.

\section{Influence of aeration on the production of coagulase}

When the medium was gently stirred, by directing a stream of air on to the surface, more coagulase ( $660 \mathrm{units} / \mathrm{ml}$.) was produced than in a control nonaerated flask ( 330 units $/ \mathrm{ml}$.). Incubation beneath a vaseline seal resulted in a lower yield of coagulase (100 units $/ \mathrm{ml}$.). No attempt was made to separate the effects of aeration and agitation. 
Table 6. Influence of the initial $p H$ of the medium on the production of coagulase by staphylococci

Strain: E.E.; 0.4 mg. dry wt. cells $/ \mathrm{ml}$. Medium: $1 \%$ proteose peptone; $0.5 \% \mathrm{NaCl}$; $0.25 \% \mathrm{Na}_{2} \mathrm{HPO}_{4} ; 10 \%$ rabbit serum. Incubation temperature $37^{\circ}$.

\begin{tabular}{|c|c|c|c|c|c|c|c|}
\hline \multicolumn{8}{|c|}{ Period of incubation } \\
\hline \multicolumn{2}{|c|}{$0 \mathrm{~min}}$. & \multicolumn{2}{|c|}{$30 \mathrm{~min}$. } & \multicolumn{2}{|c|}{$60 \mathrm{~min}}$. & \multicolumn{2}{|c|}{90 min. } \\
\hline pH & units $/ \mathrm{ml}$. & pH & units $/ \mathrm{ml}$. & $\mathrm{pH}$ & units $/ \mathrm{ml}$. & pH & units $/ \mathrm{ml}$. \\
\hline $6 \cdot 15$ & $<10$ & $5 \cdot 85$ & $<10$ & $5 \cdot 62$ & $<10$ & $5 \cdot 56$ & $<10$ \\
\hline 6.92 & $<10$ & $6 \cdot 67$ & 29 & $6 \cdot 50$ & $\mathbf{3 3}$ & $6 \cdot 46$ & 40 \\
\hline $7 \cdot 62$ & $<10$ & $7 \cdot 21$ & 67 & $6 \cdot 95$ & 84 & $6 \cdot 89$ & 84 \\
\hline $8 \cdot 39$ & $<10$ & $7 \cdot 66$ & 84 & $7 \cdot 26$ & 84 & $7 \cdot 24$ & 100 \\
\hline $9 \cdot 30$ & $<10$ & $8 \cdot 40$ & 29 & $7 \cdot 67$ & 84 & $7 \cdot 61$ & 120 \\
\hline 9.95 & $<10$ & $10 \cdot 03$ & $<10$ & $9 \cdot 93$ & $<10$ & $9 \cdot 74$ & $<10$ \\
\hline
\end{tabular}

See Fig. 2.

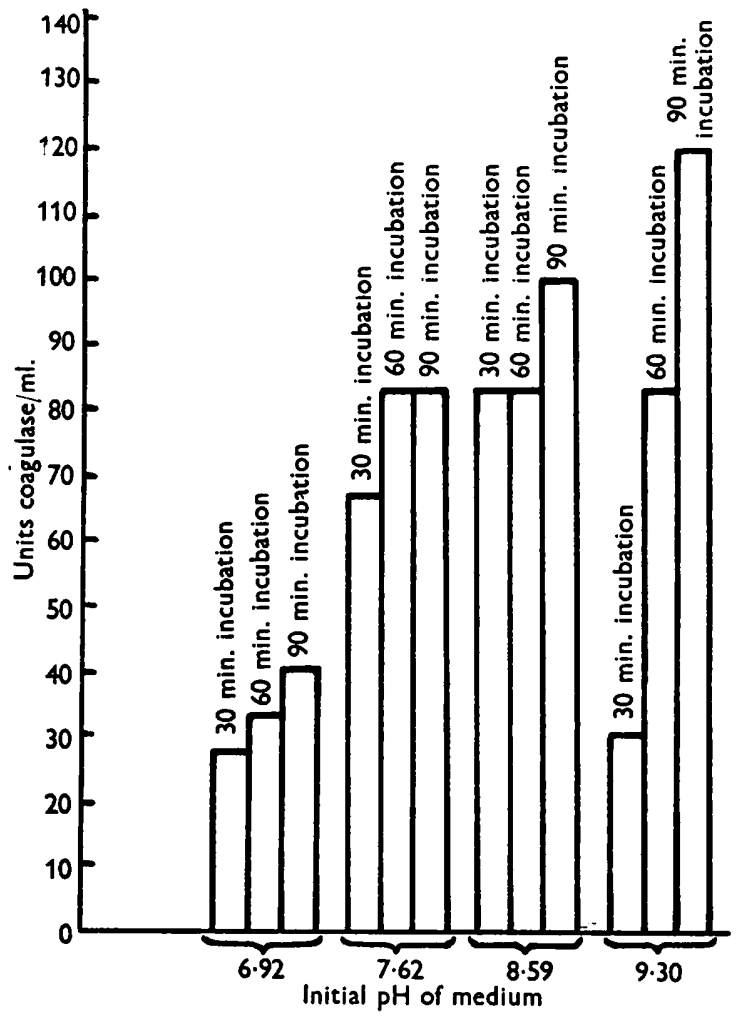

Fig. 2. Influence of the initial pH of the medium on the production of coagulase by staphylococci in glucose-peptone medium containing rabbit serum.

\section{Influence of cell concentration}

For each strain of organism there is an optimum concentration of staphylococci for the production of coagulase. For instance, Staph. aureus strain BB 
in brain-heart infusion with $10 \%$ rabbit serum produced 200 coagulase units $/ \mathrm{ml}$. when the cell-concentration was between 3.5 and $7 \cdot 0 \mathrm{mg}$. dry wt. $/ \mathrm{ml}$; at $35 \mathrm{mg} . / \mathrm{ml}$. only 50 units coagulase $/ \mathrm{ml}$. were produced.

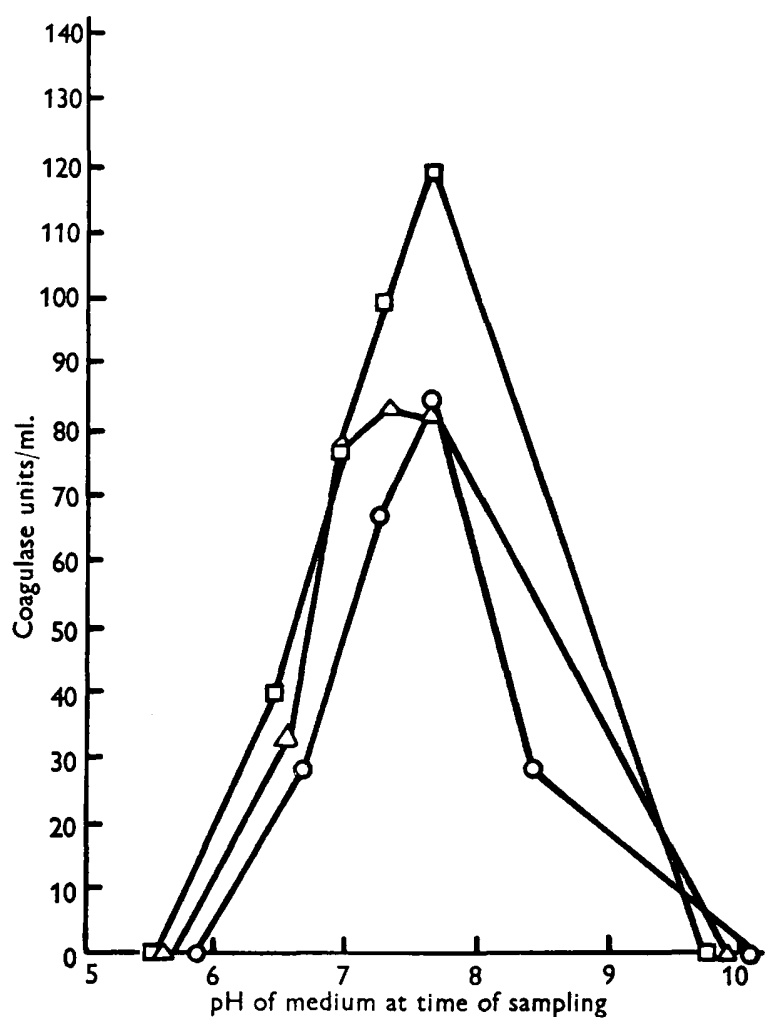

Fig. 3. Relationship between actual $\mathrm{pH}$ of medium at time of sampling and the concentration of coagulase contained in the sample. Results from experiment which is also illustrated in Fig. 2. $O-O, 30$ min. incubation; $\Delta-\Delta, 60$ min. incubation; $\square-\square$, 90 min. incubation.

\section{Influence of temperature}

Coagulase is produced at temperatures between 20 and $40^{\circ}$, with a maximum yield at about $35^{\circ}$. An experiment in which the staphylococci were incubated in brain-heart infusion with $10 \%$ rabbit serum at various temperatures gave the following results: $2^{\circ},<5$ units coagulase $/ \mathrm{ml}$; $20^{\circ}, 40$ units $/ \mathrm{ml}$.; $30^{\circ}$, 200 units $/ \mathrm{ml}$.; $35^{\circ}, 250$ units $/ \mathrm{ml} ; 40^{\circ}, 140$ units $/ \mathrm{ml}$. $45^{\circ}<5$ units $/ \mathrm{ml}$.

\section{Influence of concentration of salt}

The total salt concentration influences the yield of coagulase. An optimal salt concentration was reached at $0.5 \% \mathrm{NaCl}$ with $0.25 \% \mathrm{Na}_{2} \mathrm{HPO}_{4}$. With concentrations of $\mathrm{NaCl}$ greater than $5 \%$ no coagulase was produced. 


\section{DISCUSSION}

At a particular phase of their growth, corresponding to the latter part of the lag-phase, staphylococci, in defined conditions of cell-concentration, $\mathrm{pH}$, temperature and composition of medium, and in the presence of a protein in rabbit serum, produced a large amount of coagulase within a few minutes. In the absence of serum under the same conditions only a small amount of pro-coagulase was produced. These observations may be interpreted in two ways: (1) The cells form pro-coagulase in large amounts on their surface during the lag-phase. Normally this pro-coagulase is mainly bound to the surface and only a small proportion is shed into the medium. Serum-factor disrupts this bond with the consequent liberation of pro-coagulase and the formation of coagulase. As the age of the cells increases, during the phase of active celldivision, the pro-coagulase at the cell-surface, but not that in the surrounding medium, is destroyed and the subsequent addition of serum is without effect. (2) The cells form pro-coagulase in small amounts during the lag-phase and shed it in the surrounding medium. Serum-factor accelerates this formation of pro-coagulase. When cell-division starts, pro-coagulase is no longer produced.

We have seen from the experiment shown in Table 3 that serum exerts its effect with great rapidity since, when the cells are $60 \mathrm{~min}$. old, serum can cause the formation of a maximal amount of coagulase in less than $5 \mathrm{~min}$. The speed of this reaction is more in accordance with the hypothesis that already-formed pro-coagulase is liberated, than that which assumes the production of fresh coagulase. This transient production of a substance by young cells is reminiscent of capsule formation (Lyons, 1937). The possible identity of the serum-factor with the reaction-factor of Smith \& Hale (1944) remains to be considered. The broth-factors appear to function simply as nutrients, i.e. they assist the cells to start their growth-cycle.

If these results can be applied to the more complex conditions obtaining in vivo, they enable us to put forward the following picture of the sequence of events taking place in the formation of a staphylococcal lesion. When bacteria gain access to the tissues, there is a time-lag before cell-division starts. During this lag-period the defence mechanisms of the host are being mobilized with great speed and the organism must protect itself with even greater speed if it is to establish itself. We have seen from the experiments described above that staphylococci can produce coagulase within a few minutes. Hale \& Smith (1945) have shown that coagulase forms a barrier of fibrin round the bacteria and protects them from phagocytosis. The production of too much coagulase would be a liability to the organism, since an impermeable barrier of fibrin would prevent diffusion of nutrient material, and would also be a mechanical hindrance to colonial expansion. But we have shown that coagulase is produced only during the lag-phase, and furthermore, certain strains of staphylococci can produce a fibrinolysin (Christie \& Wilson, 1941) which will destroy the already-formed barrier. According to this view, therefore, the establishment of a staphylococcal lesion is an orderly sequence of 
events: the initial inoculum is protected from phagocytosis by a barrier of fibrin; later this barrier is removed and by this time the cells have elaborated a series of toxic principles (haemolysins, leucocidins, hyaluronidase, etc.) to assist them in their conflict with the phagocytes and to further the development of the lesion.

I wish to record my gratitude to Dr J. M. Pryce for his help with various chemical aspects of this work, particularly with regard to the establishment of the assay process.

\section{REFERENCES}

Christie, R. \& Keogh, R. V. (1940). Physiological and serological characteristics of staphylococci of human origin. J. Path. Bact. 51, 189.

Christie, R. \& Wilson, H. (1941). A test for staphylococcal fibrinolysis. Aust. J. exp. Biol. med. Sci. 19, 329.

Fairbrother, R. W. (1940). Coagulase production as a criterion for the classification of the staphylococci. J. Path. Bact. 50, 83.

Fisher, A. M. (1936). The plasma-coagulating properties of staphylococci. Johns Hopk. Hosp. Bull. 59, 393.

Fisk, A. (1940). The technique of the coagulase test for staphylococci. Brit. J. exp. Path. 21, 311.

Hale, J. H. \& SmITH, W. (1945). The influence of coagulase on the phagocytosis of staphylococci. Brit. J. exp. Path. 26, 209.

KaPlan, M. H. \& SpINk, W. W. (1948). Studies of the staphylocoagulase reaction: Nature and properties of a plasma activator and inhibitor. Blood, 3, 573.

Lyons, C. (1937). Antibacterial immunity to Staphylococcus pyogenes. Brit. J. exp. Path. 18, 411.

Miale, J. B. (1949). The role of staphylocoagulase in blood coagulation. 1. The reaction of staphylocoagulase with coagulase-globulin (C.G.) to form coagulasethrombin (C.T.). Blood, 4, 1039.

Smith, W. \& HaLE, J. H. (1944). The nature and mode of action of staphylococcus coagulase. Brit. J. exp. Path. 25, 101.

Spink, W. W. \& Vivino, J. J. (1942). The coagulase test for staphylococci and its correlation with the resistance of the organism to the bactericidal action of human blood. J. clin. Invest. 21, 353.

TAGER, M. (1948 $a$ ). Studies on the coagulase-reacting factor. 1. The reaction of staphylocoagulase with the components of human plasma. Yale J. Biol. Med. 20, 369 .

TAGER, M. (1948b). Concentration, partial purification, properties and nature of staphylocoagulase. Yale J. Biol. Med. $20,487$.

TAger, M. \& Hales, H. B. (1948). Studies on the coagulase-reacting factor. $J$. Immunol. 60, 1.

Walker, B. S., Derow, M. A. \& Schaffer, N. K. (1948). The partial purification of staphylocoagulase and the effect of certain presumptive inhibitors upon its plasma-coagulating action. J. Bact. 56, 191.

Walston, H. D. (1935). The clotting of plasma through staphylococci and their products. J. Hyg. Camb. 35, 549.

Williams, R. E. O. \& Harper, G. J. (1946). Determination of coagulase and $a$-haemolysin production by staphylococci. Brit. J. exp. Path. 27, 72.

Wright, H. D. (1933). The importance of adequate reduction of peptone in the preparation of media for the pneumococcus and other organisms. J. Path. Bact. 37, 257. 